\title{
PENYUSUNAN ENSIKLOPEDIA BIDANG SENI LUKIS KLASIK, SENI UKIR, DAN TEKSTIL DI BALI
}

\author{
I Wayan Setem ${ }^{1}$, I Wayan Mudana ${ }^{2}$ \\ Program Studi Seni Murni, Fakultas Seni Rupa dan Disain \\ Institut Seni Indonesia Denpasar ${ }^{1,2}$
}

Email: wayansetem@isi-dps.ac.id ${ }^{1}$

\begin{abstract}
This article is the result of a research aimed at describing a lexicon that summarizes various information related to fine art terms in the fields of classical painting, Kamasan wayang, carving, and textiles in Bali. As a sub-system, classic Kamasan wayang painting, carving, and textiles contain various interrelated elements, namely the concept of beauty which is the direction, techniques that are sought, disseminated and developed to give shape to the concepts of beauty, there are artists/craftsmen who manage the creation of works, the transmission of skills, techniques, functions, meanings, and historical events. The theory used is structural linguistics, lexicology and lexicography. The data collection method used in this research is the method of literature review, interviews, and historical visits followed by recording techniques. In the method of data analysis, the selection of the determining element with correlational techniques is followed by inductive and deductive analysis techniques. The results of this study indicate that there is a distinctive lexicon used by artists/craftsmen of classical Kamasan wayang painting, carving, and textiles in Bali. The lexicon consists of three categories, namely tools and materials, manufacturing processes, and aesthetics. The lexicon of the three fields of art also has two categories of functions, namely as a name and as a manufacturing process. Likewise, the various depictions/motifs have cultural values with vertical dimensions (religion and belief) and cultural values with horizontal dimensions including traditional values, feelings and peace values, nature-oriented, welfare values, and social values.
\end{abstract}

Keywords: Vocabulary, vocabulary, classical painting, carving, and textiles.

\begin{abstract}
ABSTRAK
Artikel ini merupakan hasil riset bertujuan untuk mendeskripsikan leksikon yang rangkuman informasi beragam terkait istilah-istilah seni rupa bidang seni lukis klasik wayang Kamasan, seni ukir, dan tekstil di Bali. Adapun sebagai sub-sistem, seni lukis klasik wayang Kamasan, seni ukir, dan tekstil mengandung berbagai unsur saling berkait yakni konsep keindahan yang menjadi arahan, teknik yang dicari, disebarkan dan dikembangkan untuk memberi bentuk kepada konsepkonsep keindahan, ada seniman/pengerajian yang mengelola pembuatan karya, penularan keahlian, teknik, fungsi, makna, dan peristiwa kesejarahan. Teori yang digunakan adalah linguistik struktural, leksikologi dan leksikografi. Metode pengumpulan data yang digunakan dalam penelitian ini yakni metode kajian pustaka, wawancara, dan lawatan sejarah yang dilanjutkan dengan teknik pencatatan. Dalam metode analisis data pemilihan elemen penentu dengan teknik korelasional dilanjutkan teknik analisis induktif dan deduktif. Hasil dari penelitian ini menunjukkan adanya leksikon khas yang digunakan oleh seniman/pengerajin seni lukis klasik wayang Kamasan, seni ukir, dan tekstil di Bali. Leksikon tersebut terdiri dari tiga katagori, yakni alat dan bahan, proses pembuatan, dan estetika. Leksikon ketiga bidang seni rupa tersebut juga memiliki dua katagori fungsi yakni sebagai pemberian nama dan sebagai proses pembuatan. Begitu juga pada ragam
\end{abstract}


penggambaran/motif memiliki nilai budaya berdemensi vertikal (religi dan kepercayaan) serta nilai budaya berdemensi horisontal meliputi nilai tradisi, nilai perasaan dan kedamaian, berorientasi alam, nilai kesejahteraan, dan nilai sosial.

Kata Kunci: Kosakata, kosarupa, lukis klasik, ukir, dan tekstil.

\section{PENDAHULUAN}

\section{A. Latar Belakang}

Bahasa merupakan sarana komunikasi dalam anggota masyarakat, karena dapat dipergunakan sebagai media berinteraksi mengirim informasi dalam setiap aktivitas hidup manusia. Keanekaragaman bahasa tidak dapat dipisahkan dari keanekaragaman budaya, bahkan sering sulit mengidentifikasi hubungan antarkeduanya karena bahasa dan budaya saling memengaruhi, saling mengisi, dan berjalan berdampingan. Seperti hubungan antara bahasa dan budaya dapat dilihat dari kekayaan seni rupa Bali bidang seni lukis klasik, seni ukir, dan tekstil.

Kekayaan seni lukis klasik wayang Kamasan, seni ukir, dan tekstil di Bali bukan hanya mendapat pengakuan dari berbagai kalangan seniman, juga mendapat pengukuhan dari sejarawan dan akademisi seni rupa dalam dan luar negeri. Wiyoso Yudoseputro (dalam Hardiman, 2015), menilai bahwa tidak ada daerah lain di Indonesia, kecuali Bali yang dapat menjelaskan bagaimana kedua unsur seni, asli dan baru dapat hidup bersatu dan bersenyawa. Itulah sebabnya mengapa Bali dapat menjadi sumber pengetahuan sangat penting untuk mengenal kelangsungan seni seni rupa Indonesia bahkan dunia.

Seni rupa sebagai wujud perkembangan pikiran kreatif melahirkan berbagai bentuk artefak maupun pemikiran-pemikiran yang mempunyai kaitan-kaitan tertentu dengan unsur kebudayaan lain, seperti tata masyarakat, mata pencaharian, dan agama. Di sisi lain seni lukis klasik wayang Kamasan, seni ukir, dan tekstil juga memiliki keragaman gendre, dari material tradisional hingga material modern, fungsional serta nonfungsional, hingga fungsi profane serta sakral. Adapun sebagai sub-sistem, seni lukis klasik wayang Kamasan, seni ukir, dan tekstil mengandung berbagai unsur yang saling berkait yakni ada konsep keindahan, ada teknik yang dicari, disebarkan dan dikembangkan, ada seniman sebagai pembuatan karya, sistem penularan keahlian, teknik, fungsi dan makna yang tersirat.

Seni lukis klasik wayang Kamasan, seni ukir, dan tekstil di Bali selain memiliki perwujud visual yang beragam, terdapat pula kekayaan istilah-istilah bahasa yang 
beragam di dalamnya. Kekayaan bahasa merupakan sesuatu yang menguntungkan karena bahasa termasuk aspek budaya. Suatu kebudayaan baru dapat disampaikan dan dimengerti apabila unsur kebudayaan itu mempunyai nama atau istilah. Penamaan atau pengistilahan itu menggunakan bahasa. Setiap unsur kebudayaan yang berupa kata atau leksikon diberi nama atau istilah. Pemberian nama pada kata atau leksikon tersebut bertujuan untuk mempermudah masyarakat dalam mengingat dan berkomunikasi sekaligus untuk menginventarisasi seni lukis klasik Wayang Kamasan, seni ukir, dan tekstil di Bali.

Leksikon merupakan komponen bahasa dengan satuannya leksem yang digunakan sebagai wadah bagi penyimpanan dan pengeluaran konsep-konsep, ide-ide, pengertian-pengertian yang ada dalam suatu sistem budaya (Chaer, 2007: 2). Leksikon yang diciptakan oleh sekelompok masyarakat merupakan ide masyarakat itu sendiri yang di dalamnya mengandung nilai budaya daerah setempat (Nugraheni, 2017: 42). Sehingga leksikon-leksikon yang diciptakan memiliki maksud dan tujuan yang terikat pada kehidupan sosial komunitas mereka yang khas. Leksikon tersebut terdapat pada peralatan dan bahan, proses pembuatan, serta penamaan motif bidang seni lukis klasik, seni ukir, dan tekstil diwariskan pada generasi ke generasi menggunakan istilah-istilah berupa leksikon.

Dalam penyusunan istilah-istilah bidang seni lukis klasik, patung, dan tekstil di Bali terdapat istilah berbentuk kata dasar. Kata dasar adalah satuan terkecil yang menjadi asal usul atau permulaan sesuatu kata kompleks (Tarigan, 1985: 19). Istilah yang berbentuk kata berafiks ialah istilah yang berasal dari kata dasar yang mengalami proses morfologis berupa pembubuhan afiks. Proses pembubuhan afiks ialah pembubuhan suatu satuan, baik satuan itu berupa tunggal maupun bentuk kompleks, untuk membentuk kata (Ramlan, 1985: 49). Istilah berbentuk kata ulang, ialah pengulangan satuan gramatik, baik seluruhnya maupun sebagiannya, baik dengan variasi fonem maupun tidak (Ramlan, 1985: 57). Istilah berbentuk kata majemuk, merupakan golongan dua unsur yang masing-masing memiliki makna, tetapi hasil gabungannya memiliki makna tersendiri (Djajasudarma, 1993: 47). Istilah berbentuk kata frase, menurut Ramlan (2001: 139) frasa adalah satuan gramatik yang terdiri atas dua kata atau lebih dan tidak melampaui batas fungsi atau jabatan. Istilah berbentuk klausa, adalah satuan gramatikal berupa kelompok kata yang sekurang-kurangnya terdiri dari subjek dan predikat, dan mempunyai potensi untuk menjadi kalimat (Kridalaksana, 2008: 124). 
Gagasan dalam upaya menginventerisasikan leksikon seni lukis klasik Wayang Kamasan, seni ukir, dan tekstil di Bali muncul karena melihatnya perkembangan zaman yang mempengaruhi pola pikir generasi muda era sekarang yang kurang tertarik untuk memperlajari atau menekuni ketiga bidang seni rupa Bali tersebut. Begitu juga keragaman istilah-istilah bidang seni lukis klasik wayang Kamasan, seni ukir, dan tekstil di Bali sebagai pengetahuan kesenirupaan masih tercerai-berai dan tidak beraturan, bahkan sebagian besar di antaranya belum tercatat. Apabila peristiwa tersebut berkelanjutan, maka seni rupa Bali akan tumpul dan ketrampilan tradisional pelan-pelan punah, serta kehilangan kosakata bahasa Bali sebagai warisan kultur.

Penelitian ini untuk penyusunan ensiklopedia berupa referensi atau ringkasan yang menyediakan rangkuman informasi dari bidang seni lukis klasik wayang Kamasan, seni ukir, dan tekstil di Bali untuk mendapatkan hasil terkait bentuk-bentuk istilah yang terdapat dalam konsep, alat, bahan, proses pembuatan, hasil akhir karya, estetikanya, dan makna. Sedangkan dalam analisis data istilah-istilah bidang seni lukis klasik, seni ukir, dan tekstil di Bali dipadankan atau dicarikan maknanya dalam bahasa Indonesia dengan memperhatikan keterwakilan makna dengan teknik hubung banding menyamakan.

\section{B. Metode Penelitian}

Metode yang digunakan dalam pengumpulan data, yaitu metode kajian pustaka, lawatan sejarah dengan mengunjungi situs (a trip to historical sites) ke tempat-tempat bersejarah (pura, puri/keraton, geria, cagar budaya, museum, monumen, sangging, sentra-sentra kerajianan) di seluruh Bali dan metode wawancara terstruktur dan metode simak. Untuk melengkapi metode dan teknik tersebut, maka digunakalah teknik catat agar data yang berupa istilah-istilah seni rupa Bali dapat terekam dalam kertas, sehingga peneliti tidak melakukan kelalaian dengan melupakan data yang telah dikemukakan oleh para informan.

Selain metode wawancara dan simak, digunakan metode kepustakaan. Setelah data diperoleh, data kemudian dilanjutkan pada tiga tahap berikutnya, yaitu: (1) pengaturan, (2) pengabjadan, dan (3) pemberian definisi. Seiring dengan perkembangan zaman dan teknologi tiga tahapan tersebut dapat digantikan dengan teknik yang menggunakan teknologi komputer, yaitu dengan menggunakan Microsoft Office Word dan untuk mengurutkan istilah sesuai abjad atau alfabet digunakan icon Sort. 
Teknik analisa data yang digunakan yakni metode padan dengan alat penentu berasal dari luar bahasa (Sudaryanto, 2015: 15). Metode padan sekaligus sub-jenis metode translasional memiliki teknik dasar yang disebut teknik pilah unsur penentu dibantu dengan teknik lanjutan hubung banding menyamakan (HBS) dan teknik hubung banding menyamakan hal pokok (HBSP). Dalam hal ini penelitian juga menggunakan metode agih. Sudaryanto (2015: 18) mengungkapkan bahwa metode agih merupakan metode yang alat penentunya justru bagian dari bahasa yang bersangkutan itu sendiri yang digunakan untuk menganalisis kata dan frasa dalam istilah-istilah bidang seni lukis klasik, seni ukir, dan tekstil.

Metode analisis data yang digunakan dalam penelitian ini adalah metode deskriptif kualitatif. Bogdan dan Taylor (dalam Moleong, 1989) mendefinisikan metode kualitatif sebagai prosedur penelitian yang menghasilkan data deskriptif berupa kata-kata atau lisan dari orang-orang dan perilaku yang dapat diamati. Pada penelitian ini data deskriptif yang terkumpul berupa istilah-istilah istilah-istilah bidang seni lukis klasik, seni ukir, dan tekstil di Bali. Istilah-istilah tersebut diolah menggunakan metode padan ektralingual. Metode padan ekstralingual adalah metode yang digunakan untuk menganalisis unsur yang bersifat ekstralingual, seperti menghubungkan masalah bahasa dengan hal yang berada di luar bahasa (Mahsun, 2005: 120). Unsur di luar bahasa ini maksudnya seperti hal-hal yang menyangkut makna, informasi, konteks tuturan, dan lain-lain (Mahsun, 2005: 117118).

Metode penyajian hasil analisis data menggunakan metode informal dalam hal mendeskripsikan makna istilah-istilah bidang seni lukis klasik, seni ukir, dan tekstil di Bali yang telah diperoleh. Selain menggunakan metode informal, dipergunakan pula metode formal dengan cara perumusan menggunakan lambang-lambang atau tanda-tanda yang terkait dengan penyajian dalam wajah kamus.

\section{HASIL DAN PEMBAHASAN}

Leksikon dalam seni lukis klasik wayang Kamasan, seni ukir, dan tekstil di Bali berdasarkan satuan lingual ditemukan leksikon monomorfemis, polimorfemis, dan frasa. Berdasarkan klasifikasinya leksikon-leksikon tersebut terbagi dari tiga klasifikasi yakni alat dan bahan, proses pembuatan, dan motif. Sedangkan berdasarkan kategori kelas kata 
leksikon-leksikon tersebut terdiri dari kelas kata nomina (kata benda) dan kelas kata verba (kata kerja).

Leksikon dalam seni lukis klasik wayang Kamasan, seni ukir, dan tekstil di Bali bersadarkan fungsi ditemukan dua fungsi yakni, fungsi pemberian nama dan proses pembuatan. Sedangkan leksikon tuturannya mencerminkan nilai-nilai budaya yang terdapat pada masyarakat Bali. Nilai-nilai budaya tersebut dibagi menjadi dua kategori yakni nilai budaya berdimensi vertikal dan nilai budaya berdimensi horisontal. Nilai budaya berdimensi vertikal meliputi nilai religi dan kepercayaan, sedangkan nilai budaya berdimensi horisontal meliputi nilai perasaan dan kedamaian, nilai sosial, nilai tradisi, nilai yang berorientasi dari alam, dan nilai kesejahteraan. Sehingga kebudayaan masyarakat Bali yang sudah dilupakan atau dipergunakan lagi tidak hilang karena tercermin melalui leksikon seni lukis klasik wayang Kamasan, seni ukir, dan tekstilnya.

Berdasarkan klasifikasinya leksikon-leksikon seni lukis klasik, seni ukir, dan tekstilnya di Bali diklasifikasikan berdasarkan alat dan bahan, proses pembuatan, motif, estetika dan artefak (hasil akhir). Berikut disajikan beberapa contoh entri sebagai berikut. a). Alat dan bahan yang digunakan pada seni lukis klasik wayang Kamasan yakni:

bulih : sejenis kerang yang bentuknya bulat sehingga dapat dipakai untuk menggerus permukaan kain menjadi halus dan licin pada proses pembuatan kanvas untuk melukis wayang Kamasan. Penggerusan dengan cangkang kerang sebaiknya dilakukan ketika kain dalam kondisi hangat sehabis dijemur, kemudian dibentangkan di atas papan yang permukaannya datar.

jempurit (indra) : alat untuk melubangi daun lontar/prasi di Desa Sidemen, Karangasem disebut jempurit, sedangkan di Desa Tenganan, Karangasem alat ini disebut indra. Jempurit terbuat dari kawat baja berdiameter $4 \mathrm{~mm}$. Kawat dipotong tajam berbentuk huruf ' $\mathrm{V}$ ', kemudian ujung yang berbentuk huruf ' $\mathrm{V}$ ' ditempelkan pada lontar yang akan dilubang dengan cara memutar seperti jangkar sampai lubang terbentuk dengan sempurna. Jumlah lubang disesuaikan yakni untuk lontar ukuran panjang diberi tiga lubang (ujung kiri, ujung kanan, tengah), sedang lontar yang ukuran kecil cukup diberi dua lubang pada ujung-ujungnya.

pangrupak : peralatan menulis/menggambar pada lontar menggunakan pisau khusus yang disebut pangrupak (mutik). Pangrupak digunakan untuk menggambar dengan membuat torehan pada (di atas) daun lontar. Alat tersebut juga merupakan penentu dari mutu karya yang dihasilkan. Jika diperhatikan alat tersebut juga 
memiki ragam bentuk dan ukuran sesuai kegunaan. Jadi, peralatan menggambar seni lukis prasi tidak mengunakan kuas seperti teknik melukis/menggambar pada umumnya, tetapi sebagai pengganti kuas digunakan pangrupak.

apon : cairan terbuat dari campuran ancur dan air untuk bahan pelapis/pelindung lukisan.

Setelah selesai lukisan klasik wayang Kamasan dikerjakan maka dilanjutkan dengan tahap ngapon yakni melapisi cairan ancur dan air sejenis fixsatif penguat rekatan dan kecemerlangan warna.

ancur : sejenis lem cina yang terbuat dari rebusan tulang (gelatin) ikan. Seluruh bahan pewarna tradisi pada saat penggunaannya memerlukan semacam bahan pengikat yang disebut ancur.

bak (tinta cina): merupakan produk import dari negara Cina dan sudah dikenal seniman Bali sejak lama. Berbentuknya menyerupai batang hitam bertuliskan huruf Cina. Tinta ini tetap digunakan untuk melukis dalam membuat kontur awal, pewarnaan gelap terang untuk perspektif (kesan jauh-dekat), memberikan penegasanpenegasan akhir untuk bagian-bagian tertentu yang dianggap perlu. Cara pemakaiannya dengan digosokkan pada piring/batok kelapa yang sengaja dihaluskan pada bagian dalamnya atau tempat tinta/lainnya.

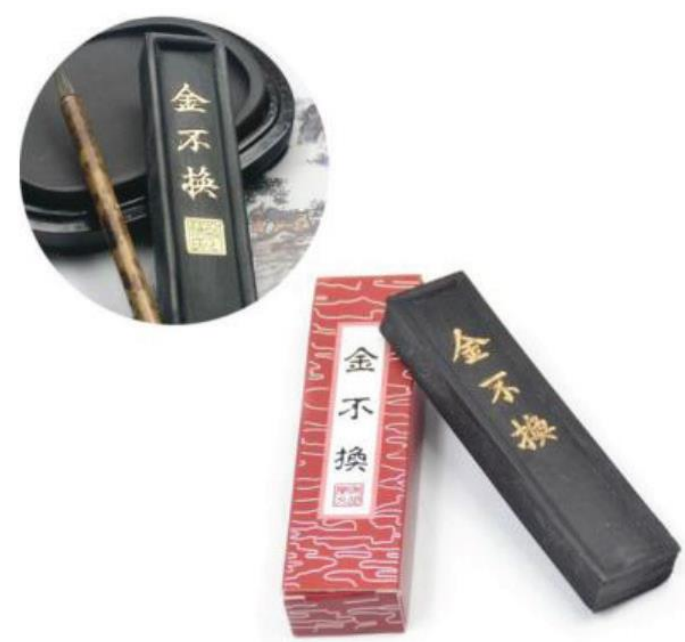

Gambar 01. Bak (tinta cina)

sumber: https://www.google.com/search-tintacinabatangan.

mangsi : warna tradisional Bali yang bahannya berasal dari endapan hitam efek asap lampu minyak kelapa. 
taum : bahan warna tradisional Bali berbahan alami yang berasal dari daun taum yang menghasilkan warna biru. Taum merupakan tanaman legum yang berbentuk perdu, masyarakat di Bali mengenal ada dua sampai tiga jenis tanaman taum yang dibedakan dari bentuk polong (buah) dan tinggi tanaman. Tanaman taum dengan batang tinggi (sekira 2,5 meter) dengan bentuk polong bengkok yang dikenal sebagai Indigofera Suffruticosa dan tanaman taum dengan batang lebih rendah (sampai dengan 1 meter) dengan bentuk polong lurus, yang disebut (Indigofera Tinctoria).

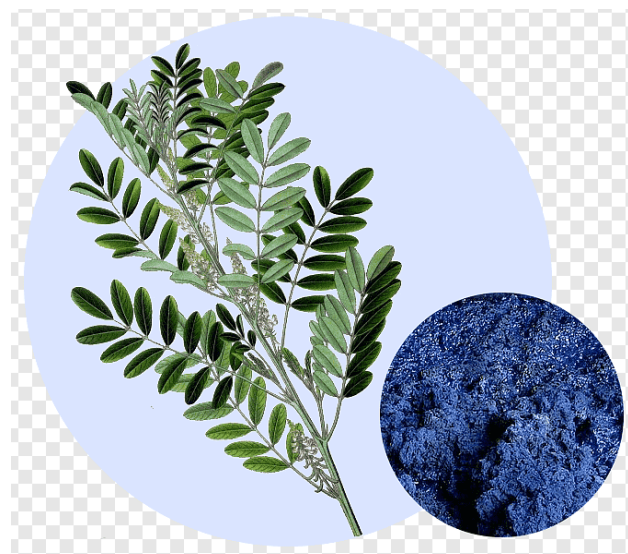

Gambar 02. bahan warna tradisional berbahan dari daun taum sumber: Setem 2021

Alat dan bahan yang digunakan pada seni ukir yakni:

paet pamuku (penguku) : pahat yang digunakan untuk menciptakan bentuk-bentuk bulatan maupun membuat bentuk cembung dan cekung, pada permukaan bentuk yang dipahat/diukir.

paet pengerancap (tatah) : pahat yang gunanya untuk melakukan pemahatan yang bersifat datar. Paet pengerancap mempunyai ukuran dari yang besar sampai yang paling kecil sesuai dengan keperluan pemahatan/ pengukir.

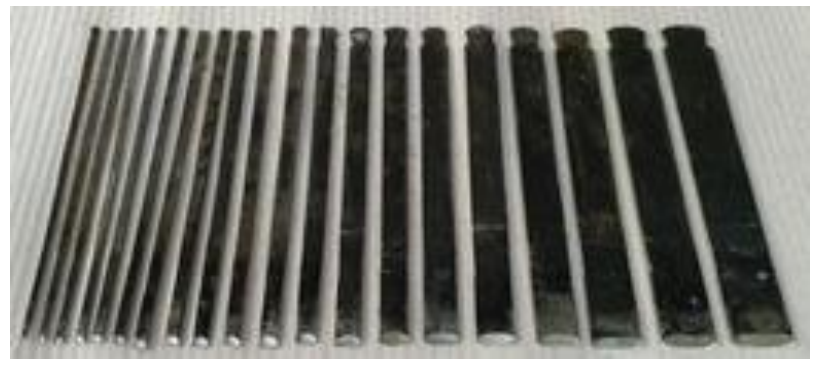

Gambar 03. Paet pengerancap (tatah) sumber: Setem 2021 
paet sesulit : pahat yang ujungnya miring

paet penyisir : pahat penyisir bagian ujungnya (bagian tajamnya) berbentuk segi tiga, fungsinya adalah untuk cawi atau membuat serat-serat dalam proses finishing pembuatan patung, panel,dan topeng.

paet bancih : pahat berbentuk setengah penguku dan setengah penepak yang berfungsi untuk membuat lengkungan dan bulatan yang lebih lebar dalam pembuatan patung, panel dan topeng.

pangot : peralatan untuk mengukir yang merupakan sebilah alat yang bermata 2 atau tajam sisi kanan dan sisi kiri, dengan bagian ujungnya melengkung sesuai dengan kebutuhan terbuat dari besi atau baja. Pangot juga dapat dipakai untuk membuat seni kriya yang cara membuatnya didominasi oleh keterampilan tangan. Peralatan pangot juga bisa berbentuk tatah pangot yang digunakan untuk membuat bentuk dari kerajinan kriya ukiran timbul, ukiran lubang, dan membuat cekungan.

c). Alat dan bahan yang digunakan pada seni tekstil yakni:

apit : bagian dari peralatan tenun tradisional yang terletak di depan perut penenun untuk menggulung tenunan yang sudah jadi.

bum (dii) : bagian dari alat tenun bukan mesin (ATBM) merupakan gulungan benang yang digunakan sebagai bahan baku untuk kain yang melintang (panjang kain/benang lungsi).

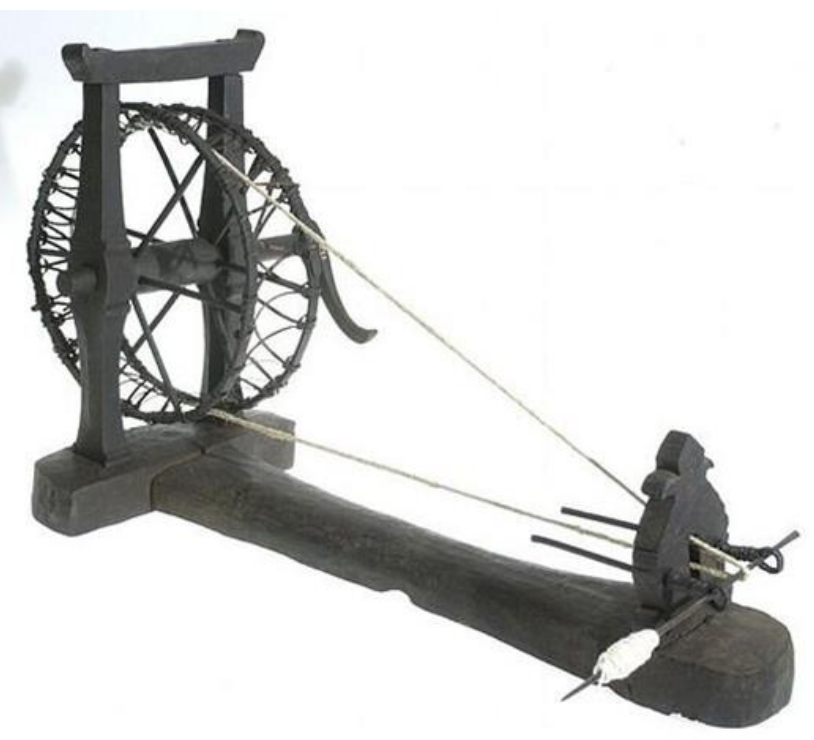

Gambar 04. Jantra merupakan alat pemintal tradisional Sumber: Setem 2021 
cacag : alat tenun tradisional menggunakan por (semacam busur).

guun : bagian dari Alat Tenun Bukan Mesin (ATBM) merupakan alat untuk mengatur benang, Terdiri atas 2 bagian, yaitu guun depan dan guun belakang.

jantra : bagian peralatan tenun tradisonal yang terbuat dari kayu dan roda. Jantra merupakan alat pemintal tradisional yang berfungsi untuk memintal dan atau menggulung benang. Proses memintal disebut ngantih.

penekek : perangkat alat tenun tradisional cagcag yang digunakan di Desa Tenganan Pegringsingan terdiri dari 2 batang lidi daun aren dengan ukuran sepanjang lebar tenun yang berfungsi untuk meluruskan pinggiran benang pakan ketika penenunan baru dimulai.

peleletan : perangkat alat tenun tradisional cagcag yang digunakan di Desa Tenganan Pegringsingan berfungsi untuk menggulung benang.

pebungbungan : perangkat alat tenun tradisional cagcag yang digunakan di Desa Tenganan Pegringsingan terbuat dari bambu yang berfungsi untuk menaik turunkan benang lungsi dengan mengorek benang untuk merapatkan tenunan dan mempertemukan warna benang sehingga membentuk motif tenunan.

penyetetan : merupakan alat pemintalan kapas untuk pembuatan tenun gringsing terbuat dari batang bambu dan benang yang agak tebal, bentuknya sangat mirip dengan busur panah. Fungsinya untuk membersihkan dan menggemburkan kapas agar ketebalan benang menjadi merata.

pengelimbengan : bagian alat menenun tradisional yang terbuat dari kayu dan batang pohon aren yang berfungsi untuk menggulung benang pakan sebelum dipindah kedalam pementang. Proses penggulungan benang dengan pengelimbengan disebut ngelimbengang.

peleting : bagian alat menenun tradisional yang digunakan sebagai tempat melilitkan benang pakan. Ketika akan menggulung benang, peleting dimasukkan ke dalam lubang bala-bala.

gambir : genus tumbuhan yang termasuk suku rubiaceae. Di Indonesia gambir pada umumnya digunakan untuk menyirih. Kegunaan yang lebih penting adalah sebagai bahan penyamak kulit dan pewarna seni membatik.

sutera : serat berbentuk figmen yang dihasilkan oleh sejenis serangga, dan tergolong ke dalam serat protein yang diperoleh dari kepompong ulat. Sutera memiliki sifat-sifat ringan, licin, berkilauan dan dapat menyesuaikan dengan temperatur. 
d). Proses pembuatan karya dalam seni lukis klasik wayang Kamasan yakni:

mulunin : tahap pemberian bulu, rambut, kumis, dan alis pada bagian bagian wayang yang dibuat. Jenis bulu maupun kumis akan berbeda beda sesuai karakter wayang. seperti wayang dengan karakter manis kumisnya akan cenderung tipis sedangkan wayang dengan karakter keras kumisnya akan cenderung tebal dan jering atau jabrik dalam bahsa Indonesia.

medapain : teknik melukis dalam mengerjakan lukisan klasik Bali dengan memberi warna merah pada ujung dan tepi daun dengan tujuan untuk menyemarakkan dekorasi dedaunan dan rerumputan. Medapain juga berfungsi menambah/ mengisi bagianbagian dengan hiasan bun tan pawi (tetumbahan tanpa ujung pangkal).

nadiang (nedegang) : proses membuat warna tradisional. Setelah warna dihaluskan, diisikan air untuk melarutkan lalu dicampur dengan ancur atau lem kayu, langkah berikutnya adalah nedegang/nadiang menjadi warna siap dipakai.

neling : memberikan karakter galak, seram, menakutkan, dengan cara membuat mata wayang melotot atau dibuat besar (dedelingan). Neling juga berarti teknik melukis dalam mengerjakan lukisan klasik Bali dengan memberikan goresan pada garis sket dengan penelingan untuk membangkitkan garis sket. Pena (penelak) penelingan goresannya lebih besar dari pena penyawian.

ngedum karang : pembagian bidang dikenal dengan istilah ngedum karang. Kata ngedum berarti membagi, sedangkan karang berarti bidang. Jadi, ngedum karang berarti membagi bidang lukis menjadi beberapa bagian sehingga lay out lukisan tampak seimbang. Langkah tersebut merupakan tahapan awal dari proses melukis tradisional wayang Kamasan, artinya pembagian ruang. Kalau dihubungkan dengan proses menggambar tradisi wayang Kamasan dengan medium kanvas, artinya sebidang kanvas yang dibagi menjadi beberapa bagian untuk menempatkan tokoh-tokoh wayang, dikelompokkan sedemikian rupa sesuai dengan stratifikasi atau tingkatan wayang sehingga tidak menyalahi pakem-pakem tradisi.

nyawi : proses penciptaan seni lukis klasik dan tradisional Bali melalui tahapan membuat kontur (nyawi). Nyawi yang artinya menegaskan sket yang dari pensil dengan tinta hitam yang pekat dan pasti tidak akan berubah lagi. Nyawi dengan menggunakan pena yang biasanya dibuat dari bambu yang dibentuk runcing sehingga menghasilkan garis tajam, kuat dan tidak luntur. Nyawi sering disebut "nyawis" 
(bahasa Bali) yang artinya selesai. Kegiatan nyawi merupakan tahap terakhir atau finishing touch dan menandakan lukisan sudah selesai dikerjakan.

nyenter : proses penciptaan seni lukis klasik dan tradisional Bali melalui tahapan nyenter. Nyenter (lampu senter yang menghasilkan sinar) yaitu tahapan penyelesaian atau finishing dengan memberikan penyinaran (memberikan sinar) pada bagian-bagian bentuk yang menonjol, agar tampak lebih kontras.

e). Proses pembuatan karya dalam seni ukir yakni:

macal (macalin) : tahapan proses pembuatan patung tradisi dengan membuat formula bentuk global dari sebuah karakter patung dengan teknik mengurangi material batu padas dengan alat patuk.

mayasin : tahapan proses pembuatan patung tradisi yang merupakan tahap penerapan ornamen keketusan dan pepatran sebagai penghias.

mubuk : proses kerja membuat wayang kulit dengan tahapan membuat lubang-lubang dengan pahat khusus yang disebut pemubuk, lubang dibuat berjajar sehingga membentuk sebuah garis, baik garis lengkung, garis lurus maupun lingkaran sesuai dengan ornamen yang ditampilkan. Di samping sebagai hiasan, bubukan ini berguna sebagai garis pemisah antara ornamen dengan badan wayang. Dengan adanya ukiran mubuk ini akan menghasilkan kontur tembus, sehingga pada saat disinari akan terlihat garis badan dan garis pakaian wayang, dengan demikian akan terbentuk bayangan wayang yang utuh.

ngemuanin : proses pengerjaan seni patung tradisi dengan membuat karakter wajah.

ngerupa : proses pengerjaan topeng/pungalan barong dan rangda pada tahapan menajamkan pola garis pada bagian membentuk mata, menajamkan pola garis pada mata, bibir dan gigi, hidung, pipi, dahi dan pada rahang atas, kumis, menggunakan alat temutik dan pangot. Pekerjaan bagian dalam topeng menggunakan alat pahat dan pangot. Berdasarkan pengamatan, bahwa dalam proses ngerupa ini sudah tampak bentuk-bentuk detil topeng yang dibuat, sehingga dapat diterka, topeng apa yang sedang dibuat.

nganasin : tahap pengerjaan patung dengan pembentukan sederhana daripada bagianbagian tertentu seperti pada wajah, posisi tangan, gerak kaki, atribut karakter ditentutkan dan dibentuk . 
f). Proses pembuatan karya dalam seni tekstil yakni:

mengulak: proses menggulung benang sehingga memudahkan penggunaan benang saat proses pertenunan.

nyipat benang: proses pengikatan benang pada tenun Gringsing dengan memberi tanda berupa garis hitam sebagai batasan medbed (mengikat) benang sebelum dicelup. nganyinin : memutar benang untuk menyusun putaran benang lungsi sehingga terpisah antara lungsi atas dan bawah.

nyuluh : proses memasukkan benang ke dalam mata sisir satu persatu dengan tujuan agar benang tersusun rapi dan tidak kusut serta memudahkan saat proses pembentukkan pola.

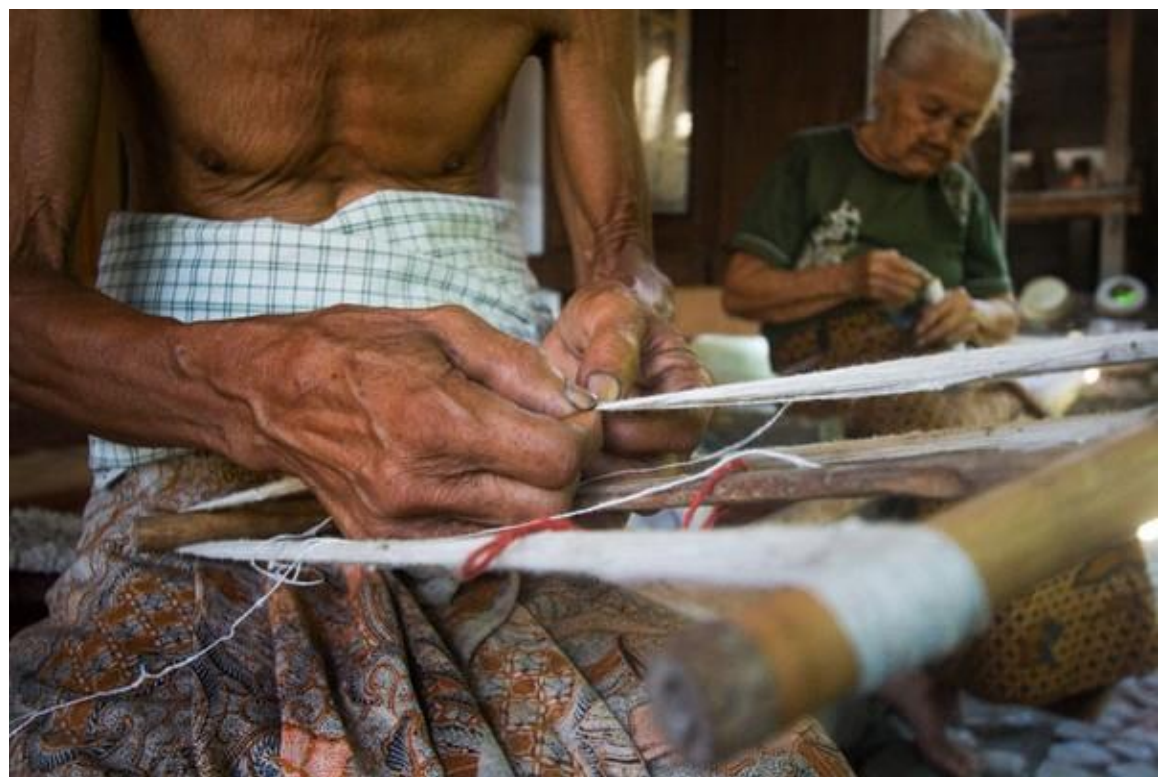

Gambar 05. Nyuluh memasukkan benang ke dalam mata sisir Sumber: Setem 2021

nyasah : penggulungan benang sehingga pas dengan jarak kayu penyangga tenun cagcag (bungan cagcag) dengan ikat punggung penenun (backstrap).

g). Estetika karya dalam seni lukis klasik wayang Kamasan yakni:

kekuwub rentet : perbandingan ukuran atau dimensi figur wayang yang biasanya digunakan untuk menghias bidang-bidang yang sifatnya memanjang, seperti iderider, pedapa, dan palelintangan. Dengan bidang terbatas posisi yang memanjang (landscape) diperlukan inovasi dari pelukis untuk mendistorsi figur-figur wayang dengan ukuran yang "tidak wajar" tetapi tetap memberikan kesan harmonis. Untuk 
memperoleh proporsi rentet digunakan kepala sebagai patokan atau gegulak dengan perbandingan 3,5 - 5,5 dikalikan ukuran kepala.

kekuwub nyepek (jengki) : perbandingan ukuran atau dimensi figur wayang yang biasanya digunakan untuk menghias bidang-bidang yang sifatnya ideal. Perbandingan ukuran tinggi dengan lebar wayang memadai sehingga tercipta figur-figur wayang yang harmonisasi. Proporsi nyepek dibuat dengan perbandingan ukuran kepala dengan badan dan kaki biasanya digunakan patokan 7,5 - 9,5 dikalikan ukuran kepala.

kekuwub lanjar : perbandingan ukuran atau dimensi figur wayang yang biasanya digunakan untuk menghias bidang-bidang yang memiliki kesan tinggi (portrait). Penggambaran pada tempat-tempat yang memiliki kesan tersebut dilakukan dengan mendistorsi bentuk wayang dengan ukuran lebih panjang atau meninggi, yakni dengan perbandingan 9,5 ke atas dikalikan ukuran kepala sehingga kesan figur-figur wayang menjadi lebih tinggi. Dalam distorsi bentuk wayang tersebut biasanya dilakukan pada bagian bahu ke bawah, sedangkan bagian kepala dilukiskan dengan ukuran yang wajar. Lukisan wayang jenis tersebut biasanya diterapkan untuk ornamen, seperti pada langse, lamak, dan sebagainya.

mata keras/deling : penggambaran visual mata berbentuk bulat dimiliki oleh tokoh yang berwatak keras seperti Bima, Gatotkaca, para raksasa dan denawa (manusia setengah raksasa)

rupa dewa : sosok wayang yang menggambarkan perwujudan dari Tuhan Yang Maha Esa. Bila digambarkan dalam bentuk lukisan, umumnya dikelilingi sinar (aura), badannya ramping dan berbusana lengkap. Kelompok ini menempati swah loka, yakni "dunia atas", seperti Dewa Siwa, Wisnu, Brahma, Iswara, Indra, dll.

h). Estetika karya dalam seni ukir yakni:

angkup : bentuk dari unsur motif ukiran yang bentuknya selalu menelungkup. Bentuk ini selalu berada pada punggung dari daun pokok.

kuping guling : 'kuping' berarti telinga dan 'guling' merupakan istilah memasak dengan cara dipanggang. Kuping guling digunakan sebagai motif ornamen, mengimajinasikan bentuk telinga babi yang telah dimasak dengan penambahan kreasi guratan pada bagian ujung yang menyerupai daun. Kuping guling sama 
dengan cula dan jambul yang terletak di depan daun pokok. Kuping guling seperti ini di Jawa namanya sunggar.

karang/kekarangan : motif hias tradisional Bali yang sebagian besar merupakan stilirisasi dari bentuk binatang, namun ada juga kekarangan yang merupakan gubahan dari bentuk tumbuhan dan manusia. 'Karang' sebagai kata dasar yang mengandung pengertian tempat, mempunyai arti berbeda kalau diberi awalan ke- dan akhiran an. Dari kata karang kemudian menjadi kekarangan, mengandung arti rekaan atau karangan.

Pada intinya kekarangan adalah hiasan yang diterapkan pada bidang yang menonjol pada sudut bangunan maupun pada bagian tengah yang sering disebut dengan bebungkulan. Sebagian besar bentuk kekarangan adalah stilirisasi dari bentuk muka yang dikombinasi dengan motif pepatran.

Kekarangan menampilkan suatu bentuk hiasan dengan suatu karangan yang berusaha mendekati bentuk-bentuk flora yang ada dengan penekanan bagianbagian keindahan. Seperti jenis keketusan ataupun pepatran, jenis kekarangan sangat banyak ditemukan dalam ragam hias tradisional Bali. Kekarangan mengambil bentuk flora yang umum dijumpai adalah: Karang Simbar, Karang Bunga, Karang Suring. Sedangkan kekarangan yang mengambil bentuk-bentuk binatang khayal primitif yang dinamai sesuai dengan bentukannya yaitu Karang Guak, Karang Gajah (Asti), Karang Tapel, Karang Bentulu, Karang Bhoma, Karang Sae, Karang Daun, Karang Bentala, dan Karang Pakis, dll.

keketusan : motif hias tradisional Bali yang paling sederhana, sesuai dengan namanya "ketus" yang artinya lepas atau pisah dari cabangnya seperti daun, bunga, buah, atau yang lainnya. Motif hias ini juga banyak diangkat dari penyetiliran benda yang ada di alam seperti batu, awan, air, atau garis geometris lainnya yang dibuat secara repetisi yaitu pengulangan bentuk secara berjejer. Tujuan dari pada ornamen keketusan diciptakan untuk mengisi bagian-bagian pepalihan (bagian-bagian yang berbentuk segi-empat panjang, seperti pundan berundak-undak, dan hiasan tepi dari bangunan arsitektur tradisional Bali. Ragam ornamen keketusan yakni : Keketusan Api-apian, Keketusan Kakul-kakulan, Keketusan Ganggong, Keketusan Batun Timun, Keketusan Paku Pidpid, Keketusan Kuta Mesir, Keketusan Meader Huruf 'T', dan Keketusan Meader Huruf 'L' 
lelengisan : bentuk hiasan tanpa ukiran. Bentuk-bentuk hiasan bakalan (global) dengan memainkan teknik penonjolan atau penekanan pada bahan; lelengisan umumnya disatukan dengan hiasan pepalihan.

memanisan : mengerjakan bentuk patung sesuai dengan karakter tokoh-tokoh 'manis', lembut, dan berwibawa.

i). Estetika karya dalam seni tekstil yakni:

enjekan siap : motif kain gringsing yang berbentuk jejak kaki ayam.

pola masemayut : teknik pemolaan dalam satu lembar kain terdapat kombinasi dua motif. Contohnya seperti motif wayang dengan motif cemplong, motif cecempakan dengan teteledan.

wastra gringsing kebo : ragam hias atau motif jenis kain gringsing ini berupa prembon, yaitu terdiri dari tiga atau lebih motif-motif gringsing, seperti bentuk wayang, bentuk teledu (kalajengking), gigi barong, panggal asu, pelupuh, tumpal, dan motif-motif geometris. Ciri khas dari jenis kain ini adalah terdapat empat motif keledu (kalajengking) yang ditampilkan dengan bentuk kaki-kakinya yang saling berhubungan dan dibatasi dengan motif tapak dara. Kain ini berfungsi sebagai sarana upacara, sebagai wastra menghiasi pelinggih (bangunan suci), sebagai busana penari rejang, sebagai busana untuk upacara potong gigi (mepandes/mesangih), sebagai busana pengantin.

wastra gringsing sanan empeg : kain berukuran $184 \mathrm{~cm} \times 19 \mathrm{~cm}$ dengan motif berupa pinggiran/pepuluh, bebintangan tampak dara, sigading poleng, dan kombinasi motif yang lain. Fungsi utama dari kain ini adalah sebagai sabuk atau sabuk tubuan (cawet), sedangkan fungsi khususnya adalah digunakan untuk penolak bala dan ruwatan.

j). Artepak karya dalam seni lukis klasik wayang Kamasan yakni:

ider-ider : lukisan pada kain yang memanjang ke samping dengan lebar lebih kurang $\mathbf{4 0}$ $\mathrm{cm}$ dan digantungkan pada lyst plank (kolong). Adapun motif-motif yang digambarkan pada ider-ider adalah bentuk ornamen Keketusan Ceracap, Gigin Barong, Mas-masan, Ganggang, Kuta Mesir dan gambar wayang. Ider-ider atau pengider-ider memiliki arti mandala yang merupakan arah mata angin digunakan untuk hiasan bangunan tempat suci. 
kober : lukisan pada kain berbentuk segi empat panjang yang dipasang pada sebatang tangkai. Tema yang dilukis pada kober adalah beberapa figur wayang seperti Hanoman, Garuda dengan motif api-apian, perkelahian Bima dengan dua ekor naga dan tokoh-tokoh Dewa Nawa Sanga. Hanoman maupun Garuda adalah mahluk mitologi sebagai pilihan untuk hiasan kober tidak lepas dari keistimewaannya kedua mahluk mitologi tersebut yang menguasai kedua zaman yaitu zaman kanda dan parwa (Ramayana dan Mahabharata). Kehidupan pada zaman berbeda bagi Hanoman dan Garuda adalah tanda kesetiaan yang tidak terbatas di dalam menjalankan kewajiban sebagai abdi penegak kebenaran.

langse : lukisan pada kain yang berbentuk segi empat panjang dan pada bagian atasnya diisi tali untuk menggantungkannya. Langse digunakan seperti gorden/tirai pada bangunan tradisional dan juga tirai gapura tarian-taarian. Temanya melukiskan pewayangan dan ornamen pepatran seperti Patra Punggel, Patra Sari, Patra Ulanda dan lain-lain.

pelelendon : lukisan pada kain atau kayu yang menggambarkan makna/tafsiran hubungan gempa bumi dengan hitungan waktu (wariga) dan dampak yang ditimbulkan. Apabila terjadi gempa merupakan suatu pertanda entah itu baik ataupun buruk tergantung di bulan apa gempa itu terjadi. Misalnya, apabila gempa terjadi pada bulan Kasa (1), tampak Betara Sri sedang bergoyang, ini pertanda rakyat dan negara akan aman dan sentosa. Begitupun gempa yang terjadi di bulan-bulan lainnya. Karena apabila terjadi gempa di bulan tertentu akan memiliki ramalan atau pertanda yang berbeda pula.

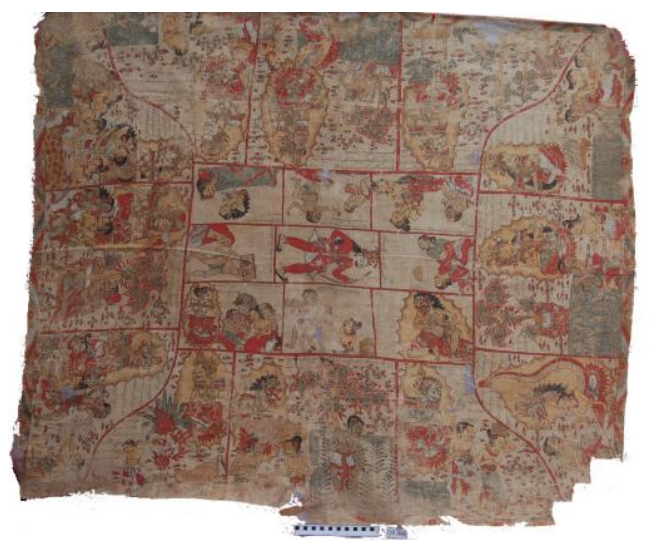

Gambar 06. Palelindon/Pelindon sumber: Koleksi Museum Bali 
k). Artepak karya dalam seni ukir yakni:

ampok-ampok : aksesoris (hiasan) busana yang dikenakan pada bagian pinggang, umumnya terbuat dari kulit sapi yang diukir dan dicat prada. Ampok-ampok miliki warna keemasan dan dasar berwarna merah.

badong : merupakan hiasan yang dikenakan pada leher. Badong seperti juga bapang ini ditatah dengan motif ornamen, dicat prada dan dilengkapi dengan pernak-pernik (permata dan kaca). Badong terdiri dari badong segitiga dan badong bundar. Badong segitiga memiliki ujung-ujung bersudut dengan untaian panjang seperti kalung yang biasanya dipakai untuk penari wanita, sedangkan bentuk badong bundar berbentuk melingkar.
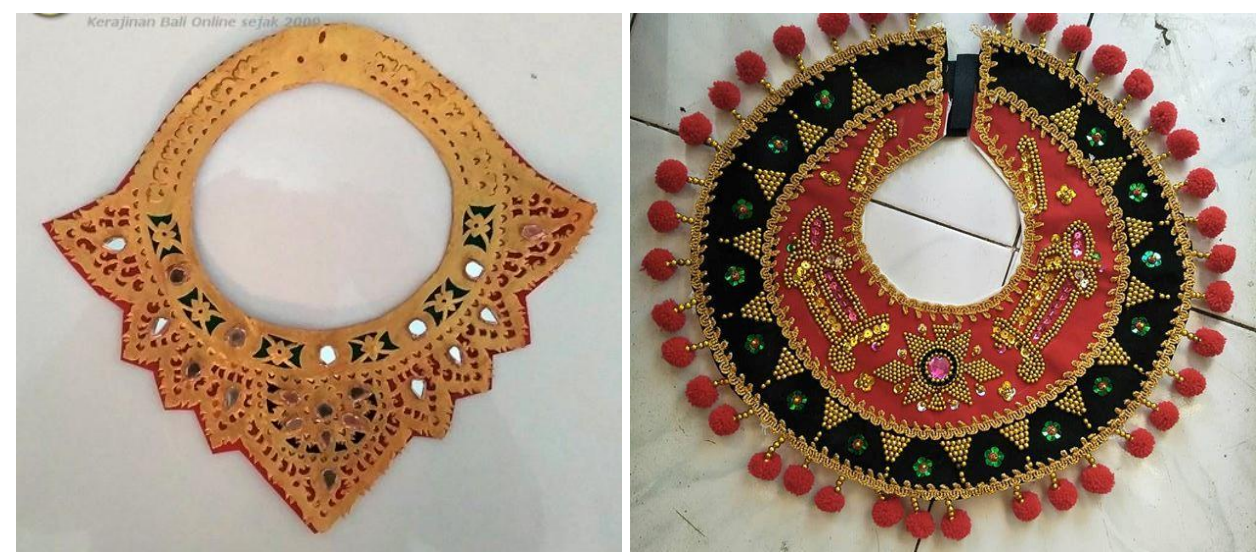

Gambar 07. Badong segi tiga dan badong bundar.

Sumber: Setem 2021

dore : hiasan punggung barong yang terbuat dari kulit yang diukir dan dihiasi dengan potongan kaca cermin.

gayor : dekorasi untuk menghias pintu gerbang pada upacara pernikahan dengan ornamen ukiran Bali yang umumnya terbuat dari gabus, papan, triplek, styrofoam sehingga menampilkan kesan indah dan elegan. Gayor pada awal kemunculannya terinspirasi dari Karang Kala yang merupakan ragam hias (ornamen) stiliran berbentuk kedok (kepala raksasa) yang digambarkan dari leher ke atas lengkap dengan hiasan, sepasang mata melotot, mulut terbuka menyeringai, memperlihatkan lidah, gigi, dan taring tajam, serta rambut ikal tebal. Karang Kala dilengkapi dengan pepatraan seperti Patra Bun-bunan dan Patra Punggel yang ditempatkan sebagai hiasan gerbang pintu masuk 
I). Artepak karya dalam seni tekstil yakni:

anteng cenik : kain yang digunakan sebagai penutup dada wanita dalam mengikuti ritual tertentu pada umumnya berukuran sekitar $665 \times 25 \mathrm{~cm}$. Anteng cenik dapat juga disebut lamak jika digunakan sebagai hiasan dalam pakaian untuk Tari Rejang.

anteng lumbang : kain yang digunakan sebagai penutup dada wanita dalam mengikuti ritual tertentu yang ukurannya lebih lebar dari anteng cening. Lumbang dalam bahasa Bali berarti lebar, maka ukuran anteng lumbang dapat dikatakan lebih besar dari anteng biasanya

kamen : merupakan selembar kain yang biasa difungsikan sebagai penutup tubuh bagian bawah pada pakaian adat Bali. Bila diamati lebih detail, kamen ini mirip dengan sarung yang bentuknya persegi dan dibuat dari bahan kain tertentu. Kain pembuat kamen biasanya merupakan kain berbahan tipis. Untuk payas agung, biasanya menggunakan kamen songket ataupun prada.

saput : kain yang digunakan sebagai pelapis sarung pakaian adat dan dalam penggunaannya dua buah saput wajib disatukan menjadi satu lembar kain (mekembar) sehingga ukurannya menjadi lebih lebar. Saput yang secara filosofis mengandung makna rwa bhineka memiliki dua ukuran yaitu: 160 x $80 \mathrm{~cm}$ yang disebut dengan patlikur dan $180 \times 100 \mathrm{~cm}$ yang disebut dengan petang dasa.

tapih : berupa kain panjang, para wanita biasanya menggunakannya hingga menutupi jari kaki atau menyentuh lantai. Kain lapis dalam yang disebut sinjang (tapih) ini berguna untuk mengatur langkah wanita agar terlihat anggun.

umpal : kain yang dipakai pria untuk memperkuat ikatan tapih dan kamen. Umpal dieratkan di sebelah kanan atau tengah namun tertutup kemeja.

wastra Poleng Rwa Bhineda : warna poleng menyerupai papan catur (kotak-kotak hitamputih) disebut dengan poleng rwa bhineda yang terdiri dua hal yang berbeda untuk mencapai keharmonisan merupakan simbolik dari dharma (kebenaran/kebaikan) dan adharma (kebatilan), unsur positif- negatif, siang-malam, panas-dingain, lakiperempuan, lingga-yoni, tinggi-rendah, gelap-terang, benar-salah dan seterusnya yang memiliki arti dua hal berbeda namun berjalan beriringan.

wastra Poleng Sudhamala : warna poleng hitam, putih, dan abu-abu ini disebut dengan poleng sudhamala. Makna yang terkandung di dalamnya yaitu warna hitam merupakan simbol adharma (unsur negatif), warna putih merupakan simbol dari dharma (unsur positif), sedangkan warna abu-abu ini merupakan warna penyelaras 
dari makna warna hitam dan putih. Motif kotak-kotak bujur sangkar yang simetris dengan warna sederhana hitam, putih, dan abu-abu membuat kain poleng sangat mudah dipadukan dengan motif dan warna lainnya. Hal tersebut disebabkan warna hitam, putih, dan abu-abu merupakan warna yang netral dalam penggolongan warna.

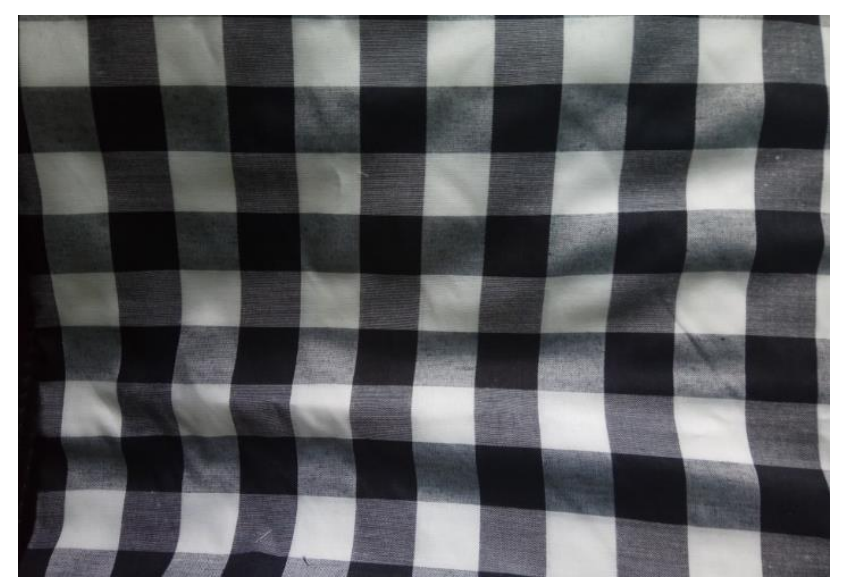

Gambar 08. Poleng Sudhamala

sumber: Setem 2021

Berdasarkan contoh interi-interi leksikon tersebut di atas, dapat diketahui bahwa keragaman nama-nama cara pembuatan, alat dan bahan, serta estetika seni lukis klasik wayang Kamasan, seni ukir, dan tekstil di Bali memiliki ciri-ciri kebahasaan, baik dari segi bentuk satuan lingual maupun makna. Leksikon-leksikon yang bervariasi hadir dalam masyarakat bukan tanpa alasan. Dalam menciptakan leksikon masyarakat tentu memerhatikan makna atau filosofi yang terkadung di dalamnya serta tidak meninggalkan nilai-nilai budaya.

\section{SIMPULAN}

Leksikon tuturan seni lukis klasik wayang Kamasan, seni ukir, dan tekstil di Bali mencerminkan nilai-nilai budaya yang terdapat pada masyarakat di Bali. Nilai-nilai budaya tersebut dibagi menjadi dua ketgori yakni nilai budaya berdimensi vertikal dan nilai budaya berdimensi horisontal. Nilai budaya berdimensi vertikal meliputi nilai religi dan kepercayaan, sedangkan nilai budaya berdimensi horisontal meliputi nilai perasaan dan kedamaian, nilai sosial, nilai tradisi, nilai yang berorientasi dari alam, dan nilai kesejahteraan. Sehingga kebudayaan masyarakat Bali yang sudah dilupakan atau 
dipergunakan lagi tidak hilang karena tercermin melalui leksikon seni lukis klasik wayang Kamasan, seni ukir, dan tekstil di Bali.

Leksikon tuturan seni lukis klasik wayang Kamasan, seni ukir, dan tekstil di Bali memiliki makna kultural yang erat kaitannya dengan kultur budaya dan hubungan sosial di masyarakat. Artinya makna sosio budaya atau makna kultural adalah makna yang memiliki kaitan erat dengan sebuah kebudayaan. Makna tersebut bisa muncul karena budaya masyarakat setempat dan hanya menjadi khas suatu budaya daerah tertentu. Konsep makna kultural ini dimaksudkan untuk lebih dalam memahami makna ekspresi verbal maupun nonverbal yang berhubungan dengan sistem pengetahuan terkait pola-pikir, pandangan hidup, serta pandangan terhadap dunia.

\section{DAFTAR PUSTAKA}

Chaer, Abdul. 2007. Linguistik Umum, Jakarta, Rineka Cipta.

Djajasudarma, T. Fatimah. 1993. Metode Lingustik (Ancangan Metode Penelitian dan Kajian), Bandung, PT Eresco.

Hardiman. 2015. Eksplo(ra)si Tubuh: Esai-esai Kuratorial Seni Rupa, Singaraja, Mahima Institut Indonesia.

Kridalaksana, Harimurti. 2008. Kamus Linguistik, Jakarta, PT. Gramedia.

Mahsun. 2005. Metode Penelitian Bahasa (Tahapan Strategi, Metode, dan Tekniknya), Jakarta, PT Raja Gafindo Persada.

Moleong, Lexy. 1989. Metodologi Penelitian Kualitatif, Bandung, Remadja Karya.

Nugraheni, Dewinta Clara (2017) "Nilai Budaya dalam Tuturan Masyarakat Perajin Tenun Ikat Tradisional Troso di Desa Troso Kecamatan Pecangaan Kabupaten Jepara" dalam Skripsi Prodi Sastra Indonesia, Jurusan Bahasa dan Sastra Indonesia, Fakultas Bahasa dan Seni Universitas Negeri Semarang, Semarang.

Ramlan, M. 1985. Morfologi Suatu Tinjauan Deskriptif, Yogyakarta. CV. Karyono.

Tarigan, Henry Guntur. 1985. Pengajaran Morfologi, Bandung, Angkasa. 